\title{
Intracellular Invasion and Killing Assay to Investigate the Effects of Binge Alcohol Toxicity in Murine Alveolar Macrophages \\ Victor Jimenez Jr",* and Fernando P Monroy\#,*
}

\author{
Department of Biological Sciences, Northern Arizona University, Flagstaff, AZ, USA \\ *For correspondence: vi92@nau.edu; Fernando.Monroy@nau.edu \\ \#Contributed equally to this work
}

\begin{abstract}
[Abstract] Alcohol consumption has diverse and well-documented effects on the human immune system and its ability to defend against infective agents. While pulmonary related infections can occur in healthy humans, binge alcohol use is recognized as a major health risk factor (Nelson et al., 1991). Although binge alcohol consumption has been considered as a risk factor for the development of pulmonary infections, no experimental studies have investigated the outcomes of a single binge alcohol exposure during infection. A key assay to assess the effects of a single binge alcohol exposure on the interactions between bacteria and alveolar macrophage is a binge alcohol intracellular invasion and killing assay. MH-S alveolar macrophages (AMs) are exposed to a single binge alcohol dose prior to infection for $3 \mathrm{~h}$. The macrophage monolayer is then infected to allow for engulfment, followed by removal of extracellular bacteria to assess the intracellular killing capacity of infected macrophages over time. We have utilized this assay to demonstrate that low alcohol exposure significantly suppressed the uptake and killing of less virulent Burkholderia thailandensis (B. thailandensis) by AMs. More recently we found that activated AMs with interferon (IFN)-y incubated in alcohol $(0.08 \%)$ for $3 \mathrm{~h}$ prior to infection showed significantly lower bacterial uptake at 2 and $8 \mathrm{~h}$ post infection, which lead to $B$. thailandensis survival and a 2.5-fold replication increase compared to controls (Jimenez et al., 2017). These results provide insights into binge alcohol consumption, a culturally prevalent risk factor, as a predisposing factor for pulmonary bacterial infections. This assay can be adapted to other bacterial species and host cell types to assess tissue specific effects of alcohol during infection.
\end{abstract}

Keywords: Alcohol, Burkholderia, Macrophage, Binge drinking, Phagocytosis, Virulence

[Background] Alcohol is widely accepted as the most popular recreational drug with well-documented adverse effects associated across geographic and social boundaries (Jones and Holmgren, 2009; Pruett et al., 2010). Studies in both human and animal models indicate that acute alcohol or binge alcohol intake, which is characterized by consumption of alcohol reaching a blood alcohol concentration of at least $0.08 \%$ within $2-3 \mathrm{~h}$, may be associated with increased health risks over the lifetime of the individual (Wechsler and Nelson, 2008; Moreira et al., 2009). We and others have demonstrated that excessive alcohol consumption is linked to impairment of macrophage function and increased risk for pulmonary infections and sepsis (Bhatty et al., 2011). Alveolar macrophages (AM) are the first line of defense during pulmonary infections, typically located in the distal respiratory tract (Knapp et al., 2003), and are capable of detecting, capturing, and eliminating invading pathogens while 
being responsible for initiating the early host immune response (Renwick et al., 2001; Qiu et al., 2012). Moreover, alcohol toxicity suppresses bacterial phagocytosis and killing in $\mathrm{J} 774.16$ macrophages when infected with Acinetobacter baumannii (Boé et al., 2001; Asplund et al., 2013). Additionally, chronic alcohol increases expression of virulence factors during infections and decreases pulmonary immune defenses in infections caused by Mycobacterium avium, Escherichia coli, Streptococcus pneumoniae, Klebsiella pneumoniae, and Staphylococcus aureus (Bermudez et al., 1993; Gordon et al., 2000; Goral et al., 2008; Camarena et al., 2010). The present assay was designed to investigate the effects of a single binge alcohol exposure on AM engulfment and intracellular killing of less virulent Gram-negative Burkholderia thailandensis. Our results indicate that a single binge alcohol episode can increase opportunistic bacterial infectivity while decreasing host innate immune responses to infection. Understanding the modulating capacity of very low alcohol exposure to alter the initial interaction between host immune mechanisms and pathogens during infection, provides important new insights into how risk factors such as alcohol can increase the infectivity of other non-virulent pathogens in otherwise healthy human hosts.

\section{Materials and Reagents}

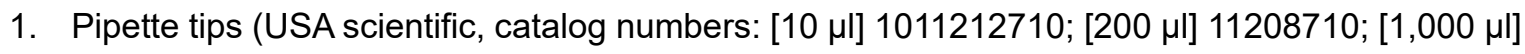
11267710)

2. T-75 tissue culture flask (VWR, catalog number: 10062860)

3. $5 \mathrm{ml}$ serological transfer pipette (Corning, Falcon, catalog number: 357543 )

4. $10 \mathrm{ml}$ serological transfer pipette (Corning, Falcon, catalog number: 356551 )

5. $25 \mathrm{ml}$ serological transfer pipette (Corning, Falcon, catalog number: 356535 )

6. Tissue culture 24-well plates (Sigma-Aldrich, catalog number: SIAL0524)

7. Sterile Petri dish (BD, Falcon, catalog number: 351029)

8. $50 \mathrm{ml}$ tube (Falcon, Becton Dickinson, catalog number:352098)

9. $15 \mathrm{ml}$ tube (Falcon, Becton Dickinson, catalog number: 352099)

10. Eppendorf tubes (1.6 ml, Flat top) (Midwest Scientific, catalog number: SS1500)

11. L-shaped spreader (USA Scientific, catalog number: 29775500)

12. Burkholderia thailandensis E264

13. $0.25 \%$ Trypsin (Gibco, Life Technologies, catalog number: 25200056 )

14. Phenol red-free RPMI-1640 medium (Life Technologies, Gibco, catalog number: 11835030)

15. Heat Inactivated FBS (fetal bovine serum) (ATCC, catalog number: 80721500)

16. 1 M HEPES (Sigma-Aldrich, catalog number: 7365459)

17. 100x Non-Essential Amino Acid Solution (ATCC, catalog number: 302116)

18. $75.0 \mathrm{~g} / \mathrm{L}$ Sodium Bicarbonate Solution (HyClone, Thermo Scientific, catalog number: $\mathrm{SH} 30033.01)$

19. 100x Antibiotic/Antimycotic Solution (J R Scientific, Inc., catalog number: 20004)

20. $1 \times \mathrm{Ca}^{2+} / \mathrm{Mg}^{2+}$-free DPBS (Gibco, Life Technologies, catalog number: A12856-01) 
21. Alveolar macrophages (AMs) (ATCC, catalog number: CRL-2019)

22. $20 \mu \mathrm{g}$ IFN-y (ProSpec-Tany TechnoGene Ltd., catalog number: Cyt358a)

23. Luria Bertani (LB) broth (BD, Difco, catalog number: 244620)

24. Luria Bertani agar (BD, BBL, catalog number: 212304)

25. Absolute Ethanol (200 proof) (Fisher Scientific, catalog number:174904)

26. Kanamycin (BioChemika, Fluka, catalog number: 42904168)

27. Clorox Germicidal Bleach (VWR, catalog number: 10028048)

28. Triton X-100 (Sigma Chemical CO., catalog number:103H0421)

29. $10 \%$ Heat inactivated FBS/1x DPBS (see Recipes)

30. $1 x$ antibiotic/antimycotic solution (see Recipes)

31. Alveolar macrophage media (RPMI) (see Recipes)

32. $200 \mathrm{U} / \mu \mathrm{I} \mathrm{IFN- \gamma} \mathrm{(see} \mathrm{Recipes)}$

33. $0.08 \%$ ethanol (see Recipes)

34. 250 or $50 \mu \mathrm{g} / \mathrm{ml}$ Kanamycin (see Recipes)

35. $10 \%$ Clorox Bleach (see Recipes)

36. $0.1 \%$ Triton $X-100$ (see Recipes)

\section{Equipment}

1. P10 Pipetman (Rainin, catalog number: A0602538G)

2. P20 Pipetman (VWR, catalog number: 041432480)

3. P200 Pipetman (VWR, catalog number: 441454097)

4. P1000 Pipetman (Gilson, catalog number: F123602)

5. Spectrophotometer (Eppendorf, BioPhotometer, model number: 613124291)

6. $37{ }^{\circ} \mathrm{C}, 5.5 \%, \mathrm{CO}_{2}$ water jacketed Incubator (Eppendorf, New Brunswick, model number: C017051201000)

7. Biosafety cabinet (Forma Scientific, model number: 1286)

8. Shallow form water bath (Bio-Rad, Sheldon Manufacturing, INC., model number: BR122)

9. Hemocytometer chamber (Hausser Scientific, catalog number: 3100 )

10. $-20^{\circ} \mathrm{C}$ freezer

11. $-80^{\circ} \mathrm{C}$ freezer

12. Inverted light microscope (VanGuard, model number: 002443)

13. Autoclave

14. Orbital floor shaker (New Brunswick Scientific CO., model number: C25)

15. Refrigerated tabletop centrifuge for $2 \mathrm{ml}$ tubes (Lab Care America, Jouan CR3, model number: CR3i)

16. Centrifuge, Sorvall legend RT+ (Thermo Scientific, catalog number: 75004377) 


\section{Software}

1. GraphPad Prism 5 (GraphPad Software)

\section{$\underline{\text { Procedure }}$}

Notes:

a. Pre-warm all tissue culture reagents (see Recipes), to $37^{\circ} \mathrm{C}$ prior to experiment.

b. This protocol was performed with sterile technique under biosafety level two conditions.

A. Grow alveolar macrophages (AMs) (Figure 1A)

1. Thaw cryovial $\left(1 \times 10^{6}\right.$ cells $\left./ 1.0 \mathrm{ml}\right)$, transfer contents of vial to a $15 \mathrm{ml}$ tube and centrifuge for 3 min at $1,300 \times g\left(4^{\circ} \mathrm{C}\right)$.

2. Decant supernatant and resuspend cell pellet in $1 \mathrm{ml}$ of pre-warmed media (see Note above).

3. Transfer cell re-suspension into a T-75 tissue culture treated flask.

4. Incubate the tissue culture flask for $48-72 \mathrm{~h}$ in the incubator (see Equipment \#6).

5. Replace media in the tissue culture flask every $24 \mathrm{~h}$ prior to experiment.

6. Allow AM's to grow to $70 \%-80 \%$ confluency in the tissue culture flask prior to use in an experimental tissue culture plate.

B. Seed AMs in tissue culture plate (Figure 1B)

1. Remove media from the T-75 flask and wash cells with $5 \mathrm{ml} 1 \times$ DPBS.

2. Discard $1 \times$ DPBS wash.

3. Trypsinize tissue culture flask by adding $3 \mathrm{ml}$ of trypsin for $4 \mathrm{~min}$ at $37^{\circ} \mathrm{C}$.

4. Gently scrape the bottom of the flask to remove attached cells.

5. Agitate flask and observe under an inverted light microscope to ensure that $>90 \%$ of the cells have detached.

6. Neutralize trypsin by adding 6-8 $\mathrm{ml}$ pre-warmed media.

7. Remove cell suspension from the flask and transfer to a $15 \mathrm{ml}$ conical tube.

8. Spin down cells at $480 \times \mathrm{g}$ for $5 \mathrm{~min}$, then remove as much supernatant as possible.

9. Resuspend cells in $3-5 \mathrm{ml}$ of RPMI (pre-warmed to $37^{\circ} \mathrm{C}$ ).

10. Take $10 \mu \mathrm{l}$ of the cell resuspension and mix with $10 \mu \mathrm{l}$ trypan blue. Calculate the concentration of the cell suspension using a hemocytometer as described in Tachibana et al. (2016 and 2017).

Equation for calculating concentration using the hemocytometer:

$$
\text { Concentration }=\frac{(\text { Total number of cells counted }) \times(\text { Dilution factor })}{(\text { Number of box counted }) \times\left(10^{-4} \mathrm{ml}\right)}
$$


11. Ensure no excessive cell doublets are present microscopically. We recommend to re-dissociate excessive cell clumping.

12. Dilute cell suspension to the actual final volume of $5 \times 10^{5} \mathrm{cells} / \mathrm{ml}$ in RPMI.

13. Aliquot $1 \mathrm{ml}$ RPMI cell suspension per well to a 24 -well flat bottom plate.

14. Incubate overnight at $37^{\circ} \mathrm{C}$ to enable cells to become adherent.

C. Challenge cells with binge alcohol dose (Figures 1C and 1D)

1. Bring absolute ethanol (200 proof) to room temperature.

2. Replace media and add media supplemented with ethanol reaching a $0.08 \% \mathrm{v} / \mathrm{v}$ concentration in $1 \mathrm{ml}$ (see Recipes).

3. For negative control add media without ethanol.

4. Challenge cells with binge alcohol dose for $3 \mathrm{~h}$.

5. Wash cells with $1 \times$ DPBS and replace media with antibiotic-free media.

Note: Incubator water bath is replaced with water supplemented with ethanol reaching a $0.08 \%$ $(\mathrm{v} / \mathrm{v})$ concentration. Atmosphere ethanol concentration is equivalent to tissue culture media alcohol concentration to minimize evaporation.

D. Stimulation (Figure 1E)

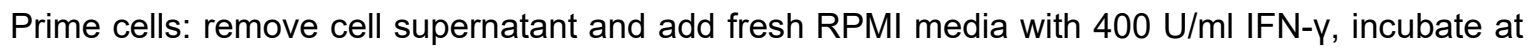
$37^{\circ} \mathrm{C}$ for 8 to $12 \mathrm{~h}$. Replace media for other wells without $400 \mathrm{U} / \mathrm{ml}$ IFN-y for "no- IFN-ү" control. Note: Alveolar macrophages are stimulated with IFN-y after alcohol challenge and prior to viable bacterial challenge. No additional exogenous LPS stimulation is required.

E. Bacterial preparation and infection (Figure 1F)

1. For each study, utilize frozen stock cultures (Burkholderia spp.) and inoculate LB broth (see Recipes) and incubate overnight at $37^{\circ} \mathrm{C}$ in an orbital shaker incubator.

2. Dilute overnight bacterial culture $1: 100(0.1 \mathrm{ml}$ into $9.9 \mathrm{ml} \mathrm{LB}$ broth $)$ and allow to grow to late-logarithmic phase measured by optical density (OD) at $600 \mathrm{~nm}$.

3. When $\mathrm{OD}$ reaches 0.3 to 0.5 absorbance, collect bacteria in $1 \mathrm{ml}$ by centrifugation $(2,500 \mathrm{xg}$ for $5 \mathrm{~min}$ ) and resuspend in $1 \mathrm{ml}$ of antibiotic-free RPMI media.

4. From preliminary colony forming unit (CFU) plate counts, adjust the volume to provide multiplicity of infection (MOI) of 1:1 CFUs in $20 \mu$ l. Determine the $\mathrm{MOI}(\mathrm{MOI}=$ number of bacteria per alveolar macrophage cell) and alter the inocula preparation accordingly. For an MOI of 1 , add $5 \times 10^{5} \mathrm{CFU}$ of $B$. thailandensis per well containing $5 \times 10^{5} \mathrm{AM}$ cells.

Note: The amount of bacterial culture added will depend upon the density of the bacteria in the media. For this assay, a cell:bacteria ratio of 1:1 is used to allow initial engulfment to occur and further intracellular killing to be monitored. A preliminary experiment should be conducted to determine total CFUs/1 ml for OD used in assay after bacteria are resuspended in antibiotic-free RPMI media. 
5. Infect alveolar macrophage monolayers per well by tilting the tissue culture plate toward you while administering the bacteria into pooled media. Do not disturb adhered macrophage monolayer with pipette tip. For negative control add 1x DPBS per well.

6. Centrifuge the cell culture plate for $5 \mathrm{~min}$ at $250 \times \mathrm{g}$ to increase interaction between cells and bacteria (see Equipment \#16).

7. Allow cells and bacteria to co-culture for $3 \mathrm{~h}$.

F. Elimination of extracellular bacteria (Figure 1G)

Note: Media and instruments in contact with viable bacteria were sterilized with $70 \%$ ethanol, $10 \%$ bleach, and DI water.

1. Discard supernatant from the tissue culture plate into $10 \%$ bleach.

2. Wash cell monolayers with pre-warmed 1x DPBS twice.

3. Replace media in the tissue culture plate with RPMI supplemented with $250 \mu \mathrm{g} / \mathrm{ml}$ Kanamycin and incubate monolayers for $1 \mathrm{~h}$.

Note: $250 \mu \mathrm{g} / \mathrm{ml}$ will eliminate $\geq 90 \%$ bacteria in $1 \mathrm{~h}$ and maintain $\geq 95 \%$ viability of macrophage cells. To maintain cell viability, antibiotic concentration is reduced after $1 \mathrm{~h}$.

4. Remove media and replace with RPMI media supplemented with $50 \mu \mathrm{g} / \mathrm{ml}$ Kanamycin.

5. Incubate cells at $37^{\circ} \mathrm{C}$ for a total of 4 and $8 \mathrm{~h}$ post infection.

G. Macrophage lysis and measurement (Figure $1 \mathrm{H}$ )

1. Discard media and replace with $0.5 \mathrm{ml}$ of $0.1 \%$ Triton $\mathrm{X}-100$ lysis buffer (see Recipes).

2. Homogenize cell monolayers completely by pipetting up and down several times using a P1000 Pipetman (i.e., at least 50 times) until no clusters of cells are observed.

3. Transfer entire contents of each well into $1.5 \mathrm{ml}$ Eppendorf tubes and label.

4. Spin down cells at $500 \times g$ for $10 \mathrm{~min}$ then remove as much solution as possible.

5. Re-suspend cells in $1 \mathrm{ml}$ of pre-warmed LB media.

6. Serial dilute (i.e., 1:10) each sample in sterile $1.5 \mathrm{ml}$ Eppendorf tubes.

7. Apply $50 \mu \mathrm{l}$ of re-suspended cell lysate onto pre-warmed LB agar plates (see Recipes).

8. Spread contents of cell lysate over the surface of the LB agar plate with a sterile L-shaped spreader (i.e., hockey stick).

9. Allow pre-labeled plates to stand right-side up for $10 \mathrm{~min}$ before inverting and storing at $37^{\circ} \mathrm{C}$.

10. Incubate LB agar plates for $48 \mathrm{~h}$.

Note: At $24 \mathrm{~h}$ incubation, plates should be removed from the incubator and CFU's quantified. Some colonies may appear after $24 \mathrm{~h}$. Plates should be validated and further analyzed at $48 \mathrm{~h}$ post initial incubation.

11. Quantify CFU's by utilizing the following equation:

(CFU's x DF)/volume spread over surface of LB plate

DF = dilution factor utilized to grow bacteria

CFU's = number of total colonies counted on a single plate 
For example: 150 colonies of $B$. thailandensis in the plate with dilution $3(1: 1,000) ; 150 \times 10^{3}$ (dilution factor) $/ 0.050 \mathrm{ml}$ (volume spread on LB plate) $=3 \times 10^{6} \mathrm{CFU} / \mathrm{ml}$
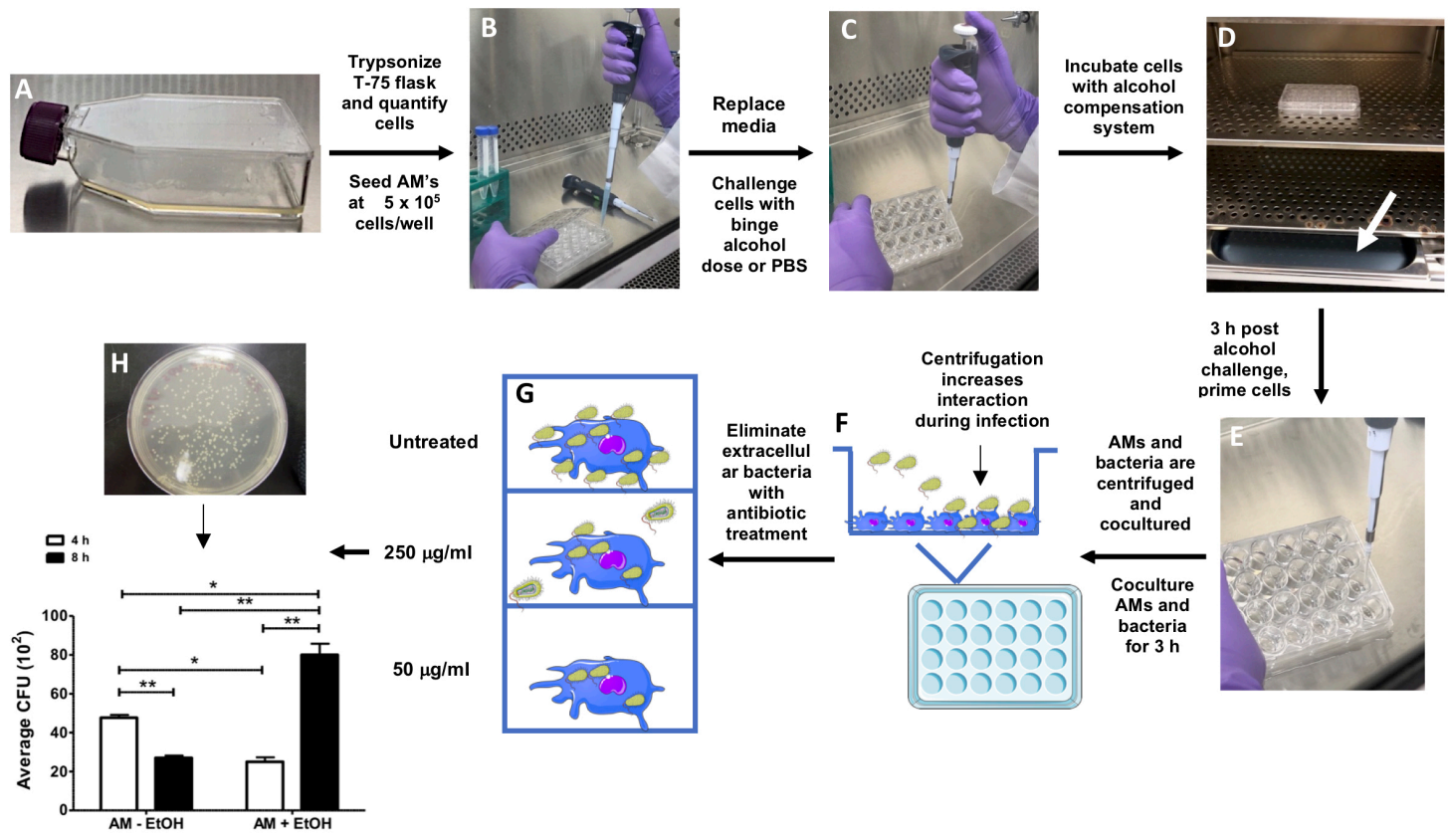

Figure 1. Representative image at different time points of binge alcohol and phagocytosis protocol. A. Alveolar macrophages (AMs) grown in a T-75 tissue treated flask. B. Quantified AMs are seeded into a 24-well plate tissue culture at a density of $5 \times 10^{5}$ cells/well. C. AMs are challenged with a single binge alcohol dose $(0.08 \% \mathrm{v} / \mathrm{v})$. D. Cells are incubated in a low evaporative tissue culture plate and the binge alcohol compensation system is applied (white arrow). E. AMs are primed with IFN-y post alcohol challenge. F. AMs are infected and tissue culture plate is centrifuged to increase AM-bacteria interaction for engulfment and intracellular invasion. G. AMs are treated with $250 \mu \mathrm{g} / \mathrm{ml}$ for $1 \mathrm{~h}$, followed by $50 \mu \mathrm{g} / \mathrm{ml}$ kanamycin to eliminate extracellular bacteria. $\mathrm{H}$. After 4 and $8 \mathrm{~h}$ post infection, AMs are washed, lysed, serial diluted, and viable bacteria grown on LB agar plates. CFUs are quantified and averaged per experimental group compared to control (non-alcohol treated cell).

\section{Data analysis}

1. For data analysis, to assess the colony forming unit (CFU) we use a minimum of three experimental replicates. For each experimental replicate, we analyzed 3 assay replicates per dilution (i.e., 3 LB agar plates for $10^{1}, 10^{2}, 10^{3}$ dilutions). We take images of each LB agar plate, count bacterial colonies on each respective LB agar plate and analyze colony formation at 24and 48-h post CFU plate formation (Jimenez et al., 2017).

2. For statistical analysis, we use GraphPad Prism. To compare two data sets, we perform a Student's $t$-test. 


\section{$\underline{\text { Notes }}$}

1. When centrifuging the bacterial sub-culture, we recommend an optical density (OD) near 0.5 as you may lose bacteria during resuspension in RPMI antibiotic-free media.

2. We recommend making all reagents fresh prior to use.

3. The protocol can be adapted to test the effects of binge alcohol toxicity on AMs with different bacterial (wild-type) infections.

Note: Preliminary studies should be conducted to determine bacterial growth conditions and antibiotic sensitivities prior to AM infection.

\section{Recipes}

1. $10 \% \mathrm{FBS} / 1 \times$ DPBS $(10 \mathrm{ml})$

Note: Make fresh prior to use.

a. In $9 \mathrm{ml}$ of $1 \times$ DPBS, add $1 \mathrm{ml} \mathrm{FBS}$

b. Filter sterilize $(0.22 \mu \mathrm{m})$, aliquot and store at $-20^{\circ} \mathrm{C}$

2. $1 \mathrm{x}$ antibiotic/mycotic $(10 \mathrm{ml})$

In 9,900 $\mu \mathrm{l}$ of $1 \mathrm{x}$ DPBS, add $100 \mu \mathrm{l}$ of antibiotic/mycotic (100x)

3. Alveolar macrophage media (RPMI)

Note: Media is made in $50 \mathrm{ml}$ stocks.

Add all of the components:

$0.5 \mathrm{ml}$ HEPES

$0.75 \mathrm{ml}$ Sodium-bicarbonate

$0.5 \mathrm{ml}$ non-essential amino acids

$0.5 \mathrm{ml}$ antibiotic/mycotic (1x)

$5 \mathrm{ml} \mathrm{FBS}$

$42.75 \mathrm{ml}$ of RPMI media

Note: Basal media arrives supplemented with L-glutamine from purchase provider.

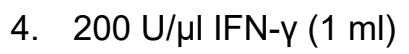

a. Specific activity is $2 \times 10^{7} \mathrm{U} / \mathrm{mg}$ or $1 \times 10^{4} \mathrm{U} / \mu \mathrm{g}$

b. Dissolve $20 \mu \mathrm{g}$ in $1 \mathrm{ml} 1 \times$ DPBS and generate $2 \times 10^{5} \mathrm{U} / \mathrm{ml}$

c. Aliquot stock into $10,25,50 \mu$ volumes per tubes to minimize freeze-thaw cycles

d. Utilize IFN- $\gamma$ aliquots at $200 \mathrm{U} / \mu \mathrm{l}$

5. $0.08 \%$ ethanol

Note: Make fresh and allow to reach room temperature prior to use.

In $999.2 \mu \mathrm{l}$ of tissue culture media add $0.8 \mu \mathrm{l}$ of 200 proof absolute ethanol (100\%)

6. 250 or $50 \mu \mathrm{g} / \mathrm{ml}$ Kanamycin (1 ml)

a. In $1 \mathrm{ml}$ DPBS (1x), dissolve $1 \mathrm{mg}$ or $1,000 \mu \mathrm{g}$ of Kanamycin (stock)

Note: Dissolve powder completely before dilutions. 
b. In $750 \mu \mathrm{l}$ of $1 \times$ DPBS or tissue culture media, add $250 \mu \mathrm{l}$ of $1 \mathrm{mg}$ stock for $250 \mu \mathrm{g} / \mathrm{ml}$

c. In $950 \mu \mathrm{l}$ of $1 \times$ DPBS or tissue culture media, add $50 \mu \mathrm{l}$ of $1 \mathrm{mg}$ stock for $50 \mu \mathrm{g} / \mathrm{ml}$

7. $10 \%$ Clorox Bleach $(500 \mathrm{ml})$

Note: Make fresh prior to use.

In $450 \mathrm{ml} \mathrm{DI}$ water, add $50 \mathrm{ml}$ of $100 \%$ (undiluted) bleach

8. $0.1 \%$ Triton $\mathrm{X}-100(50 \mathrm{ml})$

In $49,950 \mu \mathrm{l}$ of $1 \times$ DPBS, add $50 \mu$ of (undiluted) Triton X-100

9. LB Broth (1 liter)

Dissolve $25 \mathrm{~g}$ LB Broth powder to $1 \mathrm{~L}$ of deionized water, and autoclave at $121{ }^{\circ} \mathrm{C}$ for $30 \mathrm{~min}$ and store at room temperature

10. LB plates

Add $15 \mathrm{~g}$ of agar to $1 \mathrm{~L}$ of LB broth prior to autoclave process at $121^{\circ} \mathrm{C}$ for $30 \mathrm{~min}$ and pour $\sim 20 \mathrm{ml}$ of liquid into sterile Petri-dishes. Allow media to cool and harden before use

\section{Acknowledgments}

This protocol is an extended version of the one described in Jimenez et al. (2017). The research has received funding from The Department of Defense (DTRA) [HDTRA1-14-C-0022]. We thank research associates at The Pathogen Microbiome Institute (PMI) at Northern Arizona University for helpful suggestions in optimizing this assay and to Dr. Paul Keim for the generously providing $B$. thailandensis. In addition, we thank Dr. Becky Coleman, for guidance and direction with the initial approach.

\section{Competing interests}

The authors declare that there is no conflict of interest.

\section{$\underline{\text { References }}$}

1. Asplund, M. B., Coelho, C., Cordero, R. J. and Martinez, L. R. (2013). Alcohol impairs J774.16 macrophage-like cell antimicrobial functions in Acinetobacter baumannii infection. Virulence 4(6): 467-472.

2. Bermudez, L. E., Young, L. S., Martinelli, J. and Petrofsky, M. (1993). Exposure to ethanol up-regulates the expression of Mycobacterium avium complex proteins associated with bacterial virulence. $J$ Infect Dis 168(4): 961-968.

3. Bhatty, M., Jan, B. L., Tan, W., Pruett, S. B. and Nanduri, B. (2011). Role of acute ethanol exposure and TLR4 in early events of sepsis in a mouse model. Alcohol 45(8): 795-803.

4. Boé, D. M., Nelson, S., Zhang, P. and Bagby, G. J. (2001). Acute ethanol intoxication suppresses lung chemokine production following infection with Streptococcus pneumoniae. J 
Please cite this article as: Jr and Monroy, (2019). Intracellular Invasion and Killing Assay to Investigate the Effects of Binge Alcohol Toxicity in Murine

Infect Dis 184(9): 1134-1142.

5. Camarena, L., Bruno, V., Euskirchen, G., Poggio, S. and Snyder, M. (2010). Molecular mechanisms of ethanol-induced pathogenesis revealed by RNA-sequencing. PLoS Pathog 6(4): e1000834.

6. Goral, J., Karavitis, J. and Kovacs, E. J. (2008). Exposure-dependent effects of ethanol on the innate immune system. Alcohol 42(4): 237-247.

7. Gordon, S. B., Irving, G. R., Lawson, R. A., Lee, M. E. and Read, R. C. (2000). Intracellular trafficking and killing of Streptococcus pneumoniae by human alveolar macrophages are influenced by opsonins. Infect Immun 68(4): 2286-2293.

8. Jimenez, V., Jr., Moreno, R., Kaufman, E., Hornstra, H., Settles, E., Currie, B. J., Keim, P. and Monroy, F. P. (2017). Effects of binge alcohol exposure on Burkholderia thailandensis-alveolar macrophage interaction. Alcohol 64: 55-63.

9. Jones, A. W. and Holmgren, A. (2009). Age and gender differences in blood-alcohol concentration in apprehended drivers in relation to the amounts of alcohol consumed. Forensic Sci Int 188(1-3): 40-45.

10. Knapp, S., Leemans, J. C., Florquin, S., Branger, J., Maris, N. A., Pater, J., van Rooijen, N. and van der Poll, T. (2003). Alveolar macrophages have a protective antiinflammatory role during murine pneumococcal pneumonia. Am J Respir Crit Care Med 167(2): 171-179.

11. Moreira, M. T., Smith, L. A. and Foxcroft, D. (2009). Social norms interventions to reduce alcohol misuse in university or college students. Cochrane Database Syst Rev(3): CD006748.

12. Nelson, S., Bagby, G., Andresen, J., Nakamura, C., Shellito, J. and Summer, W. (1991). The effects of ethanol, tumor necrosis factor, and granulocyte colony-stimulating factor on lung antibacterial defenses. Adv Exp Med Biol 288: 245-253.

13. Pruett, S. B., Fan, R., Cheng, B., Glover, M., Tan, W. and Deng, X. (2010). Innate immunity and inflammation in sepsis: mechanisms of suppressed host resistance in mice treated with ethanol in a binge-drinking model. Toxicol Sci 117(2): 314-324.

14. Quu, H., KuoLee, R., Harris, G., Van Rooijen, N., Patel, G. B. and Chen, W. (2012). Role of macrophages in early host resistance to respiratory Acinetobacter baumannii infection. PLoS One 7(6): e40019.

15. Renwick, L. C., Donaldson, K. and Clouter, A. (2001). Impairment of alveolar macrophage phagocytosis by ultrafine particles. Toxicol Appl Pharmacol 172(2): 119-127.

16. Tachibana, N., Cantrup, R., Dixit, R., Touahri, Y., Kaushik, G., Zinyk, D., Daftarian, N., Biernaskie, J., McFarlane, S. and Schuurmans, C. (2016). Pten regulates retinal amacrine cell number by modulating Akt, Tgf $\beta$, and Erk signaling. J Neurosci 36(36): 9454-9471.

17. Tachibana, N., Zinyk, D., Ringuette, R., Wallace, V. and Schuurmans, C. (2017). $\underline{\text { Heterochronic }}$ pellet assay to test cell-cell communication in the mouse retina. Bio-protocol 7(3): e2117. 
18. Wechsler, H. and Nelson, T. F. (2008). What we have learned from the Harvard School of Public Health College Alcohol Study: focusing attention on college student alcohol consumption and the environmental conditions that promote it. $J$ Stud Alcohol Drugs 69(4): 481-490. 